\title{
A practical approach to managing diabetes in the peri- operative period
}

\author{
L du Toit ${ }^{1} \mathrm{MB}$ ChB, FCA (SA), MMed (Anaes): T Biesman-Simons, ${ }^{1} \mathrm{MB}$ ChB, DA (SA); N Levy ${ }^{2} \mathrm{MBBS}, \mathrm{BSc}, \mathrm{FRCA}, \mathrm{FrCC}$ \\ J A Dave, ${ }^{3} \mathrm{MB} \mathrm{ChB}, \mathrm{PhD}, \mathrm{FCP}(\mathrm{SA})$, Cert Endocrinology (SA) \\ ${ }^{1}$ Department of Anaesthesia and Perioperative Medicine, Groote Schuur Hospital, Cape Town, South Africa \\ ${ }^{2}$ Department of Anaesthesia and Perioperative Medicine, West Suffolk Hospital, UK \\ ${ }^{3}$ Division of Endocrinology and Diabetic Medicine, Groote Schuur Hospital, Cape Town, South Africa
}

Corresponding author: L du Toit (leon.alive@gmail.com)

\begin{abstract}
Diabetes mellitus (DM) is a common multisystem disease with hyperglycaemia as the hallmark. It is a modifiable risk factor of complications after surgery. The incidence of DM and its impact on public health are steadily increasing globally. In South Africa (SA), it is estimated that a large proportion of people living with DM are undiagnosed. A number of international groups have addressed the problem of DM in the perioperative period, proposing guidelines for optimisation and management of these patients. The guidelines fail to address the variety of contexts within which surgery is delivered in SA. In this review, the authors discuss DM within the SA context. The article provides a range of approaches to managing the patient with DM in the perioperative period. Importantly, the perioperative healthcare provider's approach should be steered by a local multidisciplinary team that considers the evidence base in light of their resource and patient context.
\end{abstract}

S A fr Med J 2018;108(5):369-375. DOI:10.7196/SAMJ.2018.v108i5.13311

The burden of non-communicable disease in South Africa (SA) is escalating. Undiagnosed and uncontrolled diabetes mellitus (DM) are common in patients requiring surgery. Access to resources and expertise to safely control blood glucose levels in the perioperative period are variable in the SA public healthcare system. The combination of an increasing burden of disease and inadequate perioperative diabetes management is likely to increase surgical complication rates, mortality and cost of care.

This article focuses on perioperative diabetes management of type 1 and type $2 \mathrm{DM}$ patients who are undergoing surgery in a noncritical care setting. Obstetric, paediatric and critical care patients are excluded from this discussion.

\section{Burden of disease}

Type $2 \mathrm{DM}$ is the most common type of diabetes, representing $>90 \%$ of the DM disease burden in SA. The International Diabetes Federation reports that there are currently $\sim 1.8$ million adults in SA known to have DM, while a further 1.5 million adults remain undiagnosed. ${ }^{[1]}$ The SA National Health and Nutrition Examination Survey (SANHANES) 2012 showed a national prevalence of abnormal glucose regulation of $18.6 \%$, varying according to ethnicity and degree of urbanisation. According to SANHANES, $45 \%$ of people with diabetes were previously undiagnosed. ${ }^{[2}$

Over the past decade, DM has become one of the major underlying causes of mortality globally; in SA it now ranks second only to tuberculosis. ${ }^{[3]}$

The SA Surgical Outcomes Study (SASOS) reports a $10.2 \%$ prevalence of diabetes in our surgical population (5.8\% non-insulin dependent, and $4.4 \%$ insulin dependent). ${ }^{[4]}$

\section{Diabetes mellitus in the perioperative context}

The perioperative period is associated with worsening glycaemic control, probably due to the stress response of surgery ${ }^{[5]}$ Starvation, tissue trauma and pain lead to increased levels of pro-inflammatory mediators and circulating stress hormones. These substances alter insulin secretion and sensitivity, producing a state of relative insulin resistance, protein catabolism and lipolysis with liberation of free fatty acids. This state can extend for multiple days into the postoperative period, driving adverse patient outcomes. ${ }^{[6]}$ These include increased mortality, increased length of hospital stay, as well as increased infective (surgical site infections, urinary tract infections and pneumonia) and non-infective complications (cardiac events, acute kidney injury and stroke). ${ }^{[7]}$

Protocol-driven quality improvement projects result in improved perioperative glycaemic control, but strict control strategies increase hypoglycaemic events. ${ }^{[8,9]}$ As hypoglycaemia has been linked to mortality, it is essential to avoid the condition by targeting a perioperative blood glucose level in the range of $6.0-10.0 \mathrm{mmol} / \mathrm{L} .^{[10]}$ A capillary blood glucose (CBG) measurement up to $12.0 \mathrm{mmol} / \mathrm{L}$ may be tolerated for brief periods if it is regularly monitored and expected to decrease. ${ }^{[11,12]}$

Hyperglycaemia in the perioperative period may be due to physiological stress and should not be diagnosed as DM without input from the local diabetes healthcare provider. Stress hyperglycaemia without DM is a poorly understood entity, the management of which remains unclear. ${ }^{[5]}$

\section{Perioperative management}

Consider perioperative management of $\mathrm{DM}$ in three phases: preoperative, intraoperative, and postoperative.

\section{Preoperative}

In the preoperative phase the patient with DM must be identified and assessed to define a perioperative management plan. Screen for undiagnosed DM according to the Society for Endocrinology, Diabetes and Metabolism of SA (SEMDSA) guidelines. ${ }^{[13]}$ Evaluate the diabetic patient's capacity to manage the disease, chronic glycaemic 
control and invasiveness of the planned surgery. Where available, a glycated haemoglobin $(\mathrm{HbAlc})$ should be used to determine adequacy of glycaemic control in those diagnosed with diabetes. An elevated $\mathrm{HbAlc}$ correlates with poor patient outcomes after surgery and an $\mathrm{HbAlc}>8.5 \%(69 \mathrm{mmol} / \mathrm{mol})$ warrants postponement of elective surgery. ${ }^{[1,12]}$ More stringent cut-off values are recommended by some, but may currently be unattainable in many parts of SA. ${ }^{[14]}$

The patient's comorbidities and glycaemic control should always be optimised before elective surgery. In an emergency, there is little time for optimisation, as surgery must proceed promptly. Often though, patients present for surgery that is time sensitive. In this 'grey zone' between elective and emergency, the timing of surgery should be determined by a multidisciplinary team with a patientcentred discussion about how best to balance risk and benefit. ${ }^{[15]}$ The decision to proceed with surgery in the face of uncontrolled DM must acknowledge the increased risk to the patient and define ways to manage this risk.

Resources and access to expertise vary among healthcare centres. It is therefore important to choose an appropriate perioperative glycaemic management plan. Although many options are available, four are commonly used and recommended (Table 1):

- modification of usual treatment (Tables 2 and 3)

- basal-bolus subcutaneous (SC) insulin (Fig. 1)

- Alberti's glucose-insulin-potassium (GIK) intravenous infusion (Box 1)

- variable rate intravenous insulin infusion (VRIII) (Fig. 2).

Monotherapy with SC short- or rapid-acting insulin according to a sliding scale is not recommended for in-hospital management of
$\mathrm{DM}$, as it increases the risk of hypoglycaemia and provides inferior glycaemic control..$^{[16,17]}$

In all cases, limiting of the starvation period has to be planned, as well as where the patient will be managed postoperatively (day case, surgical ward or high-care facility). For short starvation periods (one missed meal), modification of the usual medication will often suffice (Tables 2 and 3). Missing more than one perioperative meal is considered a prolonged starvation period. If the CBG is $>12 \mathrm{mmol} / \mathrm{L}$, it will necessitate either basal SC insulin or an intravenous insulin infusion.

\section{Intraoperative}

The intraoperative phase starts at the time of arrival in theatre and continues until transfer to the postoperative ward. The patient with DM must have a documented CBG prior to commencement of anaesthesia. While under anaesthesia, the CBG should be monitored at least 2-hourly, more frequently if abnormal and in patients receiving insulin. ${ }^{[18]}$ If the intraoperative CBG levels were abnormal, the CBG measurement should be repeated in the post-anaesthetic recovery area.

When possible, administer SC short- or rapid-acting insulin to avoid unnecessary intravenous insulin for short surgical procedures. Limit SC short- or rapid-acting insulin to two intraoperative doses. In type $2 \mathrm{DM}$, a first dose of $0.1 \mathrm{U} / \mathrm{kg}$ (up to a maximum of $6 \mathrm{U}$ ) is appropriate; alternatively, use the correction dosing scale in Fig. 1 as a starting point. To prevent insulin stacking intraoperatively, do not administer a top-up dose of SC insulin within 2 hours of the first dose. Intravenous insulin is preferred when SC insulin does not control hyperglycaemia. This is common in surgery of longer duration, prolonged starvation and emergency cases. ${ }^{[11]}$

Table 1. Indications, advantages and disadvantages of four perioperative diabetes management strategies

\begin{tabular}{|c|c|c|c|}
\hline Management & Indications & Advantages & Disadvantages \\
\hline $\begin{array}{l}\text { Modification of usual } \\
\text { therapy }\end{array}$ & $\begin{array}{l}\text { HbAlc }<8.5 \% \\
\text { Short starvation period } \\
(<1 \text { meal missed })\end{array}$ & $\begin{array}{l}\text { Lowest risk for hypoglycaemia } \\
\text { Decreased burden on ward staff } \\
\text { Suitable for patient self-management }\end{array}$ & $\begin{array}{l}\text { Often not possible, as patients have } \\
\text { poor baseline control or there is } \\
\text { prolonged starvation }\end{array}$ \\
\hline $\begin{array}{l}\text { Basal-bolus SC insulin } \\
\text { with correction doses }\end{array}$ & $\begin{array}{l}\text { Those already on basal-bolus insulin } \\
\text { Type } 1 \text { diabetes } \\
\text { Patients with poor baseline control } \\
\text { Newly diagnosed DM requiring } \\
\text { perioperative insulin therapy } \\
\text { Short surgical duration } \\
\text { Where IV insulin therapy is not } \\
\text { feasible }\end{array}$ & $\begin{array}{l}\text { Improved glycaemic control } \\
\text { Flexible dosing } \\
\text { Decreased risk of hypoglycaemia }\end{array}$ & $\begin{array}{l}\text { Intensive } \\
\text { Regular monitoring required } \\
\text { Not to be used if the patient is not } \\
\text { eating meals } \\
\text { Unpredictable absorption when there } \\
\text { is impaired tissue perfusion }\end{array}$ \\
\hline $\begin{array}{l}\text { Alberti's glucose- } \\
\text { insulin-potassium } \\
\text { infusion }\end{array}$ & $\begin{array}{l}\text { Poor control on } \mathrm{SC} \text { insulin } \\
(\mathrm{CBG}>12.0 \mathrm{mmol} / \mathrm{L}) \\
\text { Prolonged starvation period } \\
\text { ( }>1 \text { meal missed) } \\
\text { Long surgical duration } \\
\text { Periods of inadequate tissue perfusion } \\
\text { High-care or ICU setting } \\
\text { VRIII is not an option }\end{array}$ & $\begin{array}{l}\text { Improved glycaemic control } \\
\text { Flexible }\end{array}$ & $\begin{array}{l}\text { Labour intensive } \\
\text { Need trained staff } \\
\text { Risk of hypo- } \mathrm{Na}^{+} / \mathrm{K}^{+} \\
\text {Risk of hypoglycaemia }\end{array}$ \\
\hline VRII & $\begin{array}{l}\text { Poor control with SC insulin } \\
(\mathrm{CBG}>12.0 \mathrm{mmol} / \mathrm{L}) \\
\text { Prolonged starvation period } \\
\text { ( }>1 \text { meal missed) } \\
\text { Long surgical duration } \\
\text { Periods of inadequate tissue } \\
\text { perfusion } \\
\text { High-care or ICU setting }\end{array}$ & $\begin{array}{l}\text { Improved glycaemic control } \\
\text { Flexible }\end{array}$ & $\begin{array}{l}\text { Requires specialised equipment } \\
\text { Labour intensive } \\
\text { Need trained staff } \\
\text { Risk of hypo- } \mathrm{Na}^{+} / \mathrm{K}^{+} \\
\text {Risk of hypoglycaemia }\end{array}$ \\
\hline
\end{tabular}




\begin{tabular}{|c|c|c|c|}
\hline Management & Class of drug (examples) & Considerations & Recommendations \\
\hline \multirow{6}{*}{ Insulin sensitisers } & Biguanides & Does not cause hypoglycaemia & Continue while eating \\
\hline & Metformin & Risk of lactic acidosis & Omit on day of surgery \\
\hline & & & $\begin{array}{l}\text { Omit if risk of renal impairment } \\
\text { (IV contrast, other nephrotoxic agents, } \\
\text { haemodynamic instability) }\end{array}$ \\
\hline & & & Omit if $>1$ meal missed \\
\hline & Thiazolidinediones & Does not cause hypoglycaemia & Omit on day of surgery \\
\hline & Pioglitazone (roziglitazone) & $\begin{array}{l}\text { Concern of hepatotoxicity } \\
\text { Contraindicated in } \\
\text { haemodynamic instability }\end{array}$ & Restart when tolerating meals \\
\hline \multirow[t]{7}{*}{ Secretagogues } & Sulphonylureas & Risk of hypoglycaemia & Omit while fasting \\
\hline & Glibenclamide & & Restart when tolerating meals \\
\hline & Gliclazide & & \\
\hline & Glimepiride & & \\
\hline & Meglitinides & Risk of hypoglycaemia & Omit while fasting \\
\hline & Repaglinide & & Restart when tolerating meals \\
\hline & Nateglinide & & \\
\hline \multirow[t]{6}{*}{ Incretin family } & GLP-1 analogues & Delayed gastric emptying & Limited information \\
\hline & Exenatide & concern for aspiration risk & May improve perioperative glycaemic \\
\hline & Liraglutide & Injectable only & control \\
\hline & DPP-4 inhibitors (gliptins) & & Limited information \\
\hline & Saxagliptin & & May improve perioperative glycaemic \\
\hline & Vildagliptin & & control \\
\hline \multirow[t]{3}{*}{ Increased glucosuria } & SGLT-2 inhibitors (gliflozins) & Association with DKA & Avoid in the perioperative period \\
\hline & Empagliflozin & & \\
\hline & Dapagliflozin & & \\
\hline Impairs absorption & $\begin{array}{l}\text { Alpha-glucosidase inhibitors } \\
\text { Acarbose }\end{array}$ & Causes severe flatulence and & Avoid in the perioperative period \\
\hline
\end{tabular}

Table 3. Perioperative modification of insulin therapy ${ }^{*+}$

\begin{tabular}{|c|c|c|}
\hline Insulin regimen ${ }^{*}$ & Day before surgery & Day of surgery \\
\hline Once daily (evening dosing) intermediate- or long-acting insulin & Reduce dose by $20 \%$ & Restart insulin with evening meal \\
\hline Once daily (morning dosing) intermediate- or long-acting insulin & Usual dose & Reduce dose by $20 \%$ \\
\hline Twice daily dosing & Usual dose & Reduce morning dose to $50 \%$ \\
\hline Premixed insulin, or intermediate- or long-acting insulin & & Normal evening dose with dinner \\
\hline \multirow[t]{2}{*}{ Basal-bolus regimen } & Usual bolus doses & If basal dose in the morning, reduce by $20 \%$ \\
\hline & $\begin{array}{l}\text { Reduce night-time basal } \\
\text { dose by } 20 \%\end{array}$ & Omit bolus doses while fasting \\
\hline
\end{tabular}

\section{Postoperative}

After surgery, intravenous insulin therapy must not be discontinued without overlapping and restarting the patient's basal SC insulin. Check the CBG before discharge from the post-anaesthetic recovery area. Ensure that the patient is sent to the appropriate level of care for continuation of their glycaemic control strategy. Early reinstatement of normal enteral feeding and usual antidiabetic medication is the goal. The agents and regimen used for glycaemic control will largely depend on the feeding status of the patient (Table 4).

\section{Safe insulin therapy}

Insulin is an extremely potent agent. Drug errors can cause significant harm to the patient. Staff education and involvement of the local pharmacy are needed to ensure constant safe prescribing, dispensing and dosing practices. ${ }^{[19]}$
There is a real risk of diabetic ketoacidosis (DKA) with transition to and from intravenous insulin therapy. Delays in commencing the intravenous insulin infusion, and discontinuation of the infusion prior to administration of basal insulin, cause acute insulin deficiency in insulin-dependent patients. ${ }^{[20]}$ This risk can be mitigated by continuation of basal SC insulin while using intravenous insulin, or by administration of intermediate- or long-acting insulin 30 minutes before discontinuing the intravenous insulin (GIK or VRIII). ${ }^{[12]}$

\section{Non-insulin antidiabetic agents}

Non-insulin antidiabetic agents should not be started in the immediate perioperative period. These medications have multiple contraindications and are not rapidly titratable. However, diabetic patients who are well controlled could be considered for continuation of their non-insulin agents during the perioperative period. Guidance 
Three components

- Basal - once daily intermediate- or long-acting insulin

- Bolus - dosing at meal times with short- or rapid-acting insulin

- Correction - additional dosing at meal times with short- or rapid-acting insulin

to achieve or maintain the desired individualised glycaemic target

For patients already on insulin, start with the patient's usual TDD

For insulin-naive patients, start with a TDD of $0.2-0.3 \mathrm{U} / \mathrm{kg} /$ day

$\downarrow$

Give $50 \%$ of the TDD as basal insulin

Give $50 \%$ of the TDD as bolus doses (divide into 3 equal doses and give before each meal)

$$
\downarrow
$$

Give correction doses (added to the already prescribed insulin doses) according to the following dosing scale:

\begin{tabular}{|l|l|l|l|}
\hline & \multicolumn{3}{|c|}{ Insulin correction dose, U } \\
\cline { 2 - 4 } CBG, mmol/L & $\begin{array}{l}\text { Level 1 (insulin } \\
\text { sensitive, incl. } \\
\text { fasting) }\end{array}$ & $\begin{array}{l}\text { Level 2 } \\
\text { (usual patient) }\end{array}$ & $\begin{array}{l}\text { Level } 3 \text { (insulin } \\
\text { resistant, } \\
\text { TDD >80 U) }\end{array}$ \\
\hline $10.1-12.0$ & 2 & 4 & 6 \\
$12.1-14.0$ & 3 & 6 & 9 \\
$14.1-16.0$ & 4 & 8 & 12 \\
$16.1-20.0$ & 5 & 10 & 15 \\
$>20.0$ & 6 & 12 & 18 \\
\hline
\end{tabular}

To prevent insulin stacking, allow at least 4 hours between SC doses of insulin Two-hourly dosing is acceptable intraoperatively

Reduce the basal doses to $80 \%$ of the usual dose on the night before and the morning of surgery

Omit prandial dosing while fasting

Provide hypoglycaemia management instructions wherever insulin is prescribed

Fig. 1. Basal-bolus insulin regimen. ${ }^{[16,25,26]}(T D D=$ total daily dose; $C B G=$ capillary blood glucose; SC $=$ subcutaneous. )

on the management of these agents during the perioperative period is given in Table 2 . Modification of oral therapy as the primary perioperative glycaemic control strategy is only appropriate in uncomplicated surgical patients who miss one meal during the perioperative period. Critically ill patients, those with poor glycaemic control and those who miss multiple meals, should be managed with an appropriate insulin regimen. ${ }^{[21,22]}$

\section{Hypoglycaemia}

The perioperative period represents an increased risk for undiagnosed hypoglycaemia while patients are fasting and under the influence of sedative agents. Whenever insulin is prescribed in hospital, hypoglycaemia treatment must be prescribed on the same chart. Perioperatively, a CBG $<6.0 \mathrm{mmol} / \mathrm{L}$ should be interpreted as imminent hypoglycaemia. A CBG $<4.0 \mathrm{mmol} / \mathrm{L}$ is associated with harm and must be treated. Interruption of insulin therapy is discouraged, but dose reduction may be necessary. Assess the patient with a low CBG for signs and symptoms of hypoglycaemia. Consider their feeding status (eating or fasting) and their risk of hypoglycaemia unawareness. Fig. 3 provides a suggested hypoglycaemia management algorithm. While under the influence of anaesthesia, treat all patients with a low CBG with intravenous dextrose. If the $\mathrm{CBG}$ is $<6.0 \mathrm{mmol} / \mathrm{L}$, administer $10 \mathrm{~g}$ intravenous dextrose; if the $\mathrm{CBG}$ is $<4.0 \mathrm{mmol} / \mathrm{L}$, give $20 \mathrm{~g}$ intravenous dextrose. Thereafter, the CBG should be measured every 15 minutes and treatment repeated until the blood glucose is corrected. ${ }^{[11]}$

\section{Special circumstances}

SC insulin infusion (SCII) (or insulin pump therapy) is increasingly used in the management of type $1 \mathrm{DM}$. Patients using an insulin pump should,as far as possible, maintain control of their own perioperative glycaemic management. When assessing these patients, consider the invasiveness, duration and site of the surgery, as well as the anticipated postoperative course. Question how many meals the patient will skip. Will the anaesthetist have access to the SCII intraoperatively? Will the device location infringe on the surgical site? Ideally, a preoperative basal test is done to establish glycaemic response to the fasting state. If this was not done, ask the patient to decrease the SCII to $70-80 \%$ of the basal rate while fasting. Ensure that the anaesthetic provider understands how to adjust, discontinue and remove the SCII if necessary. If continued intraoperatively, one or two small $(2-4 \mathrm{U})$ SC correctional doses of insulin may be administered if the $\mathrm{CBG}$ rises $\geq 10.0$ $12.0 \mathrm{mmol} / \mathrm{L}$. If this fails to correct the CBG, start a VRIII. If the CBG decreases to $<4.0-6.0 \mathrm{mmol} / \mathrm{L}$, treat the hypoglycaemia with intravenous dextrose. If hypoglycaemia persists, disconnect the SCII and switch to a VRIII. SCII is not appropriate for emergency surgery or where more than one meal is missed in the perioperative period. ${ }^{[23,24]}$

For patients with DM, day-case surgery must be considered. ${ }^{[14]}$ It reduces the risk of iatrogenic complications and empowers the patient to manage their own perioperative glycaemic control. When assessing diabetic patients for day-case surgery, three aspects must be considered:

- Is the patient physically, mentally and socioeconomically capable to self-manage their DM and do they have easy access to emergency healthcare should they need it?

- Is their DM adequately controlled, with a recent $\mathrm{HbAlc}<8.5 \%$ ?

- Is the nature of the surgery suitable for a day case?

\section{A multidisciplinary context- sensitive approach}

No single scenario describes every patient with DM who has to undergo surgery. At each facility (or group of facilities) a representative multidisciplinary team must evaluate the unique patient-resource environment and develop an evidence-based clinical practice guideline that fits their context. Smaller facilities should obtain input from their regional specialist centre.

It is essential to empower patients to selfmanage their diabetes, especially in a setting where access to resources or healthcare personnel is limited. When appropriate, patients should be given guidance to manage their own insulin and non-insulin antidiabetic therapy in the ward. ${ }^{[21]}$

The dietician, or equivalent team member, must engage the kitchen service to ensure 
Box 1. Alberti glucose-insulin-potassium infusion ${ }^{[21,27]}$

The GIK infusion is an alternative IV insulin regimen when a VRIII is not feasible. It provides substrate, IV insulin and electrolytes via a single infusion.

The original GIK regimen was published by Alberti and Thomas in 1979. It provides a safe and effective method of giving substrate, IV insulin in the same infusion. Alterations of the original regimen remain in use today. ${ }^{[28,29,30]}$

The original GIK regimen uses a bag containing $500 \mathrm{~mL} 10 \%$ dextrose and adds:

- $10 \mathrm{U}$ short-acting insulin

- $10 \mathrm{~mL} 10 \% \mathrm{KCl}$.

The infusion runs at a fixed rate of $100 \mathrm{~mL} / \mathrm{h}$, providing $2 \mathrm{U}$ insulin per hour.

CBG is measured 1 - 2-hourly. To increase or decrease the insulin infusion rate by $1 \mathrm{U} / \mathrm{h}$ the insulin content of the bag is changed up or down by $5 \mathrm{U}$. A new bag must be mixed each time it is decided to adjust the insulin infusion rate.

Problems with the GIK infusion are:

- labour intensive and wasteful when multiple bag changes are needed

- maintenance at $100 \mathrm{~mL} / \mathrm{h}$ exceeds current standards for care of surgical patients

- $500 \mathrm{~mL} 10 \%$ dextrose bags are not available at all locations

- $10 \%$ dextrose water is not an acceptable maintenance fluid

- risk of DKA in type 1 DM if GIK infusion is stopped.

If deemed appropriate for the location, the local multidisciplinary team must adapt the GIK regimen to suite their context and address the concerns mentioned. Involve specialist input.

$\mathrm{GIK}=$ glucose-insulin-potassium; $\mathrm{IV}=$ intravenous; $\mathrm{VRIII}=$ variable rate intravenous insulin infusion; $\mathrm{CBG}=$ capillary blood glucose; $\mathrm{DKA}=$ diabetic ketoacidosis; $\mathrm{DM}=$ diabetes mellitus

Use a dedicated IV access site and infusion set with an antireflux valve for glucose management

Add $50 \mathrm{U}$ of regular short-acting insulin to $50 \mathrm{~mL} 0.9 \% \mathrm{NaCl}(1 \mathrm{~mL}=1 \mathrm{U})$

Administer with a syringe driver connected to a port close to the dedicated IV cannula

Run dextrose-containing maintenance solution at $25 \mathrm{~mL} / \mathrm{kg} /$ day $(20-30 \mathrm{~mL} / \mathrm{kg} / \mathrm{h}$ range)

Monitor serum $\mathrm{Na}^{+}$and $\mathrm{K}^{+}$daily

Measure CBG hourly while the patient is under the influence of anaesthesia; 2-hourly if normoglycaemic, awake, attended, and not confused

\begin{tabular}{|c|c|c|c|}
\hline \multirow[b]{2}{*}{ CBG, $\mathrm{mmol} / \mathrm{L}$} & \multicolumn{3}{|c|}{ Insulin rates, $\mathrm{mL} / \mathrm{h}$} \\
\hline & $\begin{array}{l}\text { Level } 1 \text { (insulin sensitive, } \\
\text { incl. fasting) }\end{array}$ & Level 2 (usual patient) & $\begin{array}{l}\text { Level } 3 \text { (insulin resistant, } \\
\text { TDD >80 U) }\end{array}$ \\
\hline$<4.0$ & \multicolumn{3}{|c|}{$\begin{array}{l}\text { Reduce VRIII to } 0.2-0.5 \mathrm{~mL} / \mathrm{h} \text { (stop VRIII if SC basal insulin continued) } \\
\text { Administer } 20 \mathrm{~g} \text { dextrose IV } \\
\text { Repeat CBG in } 15 \mathrm{~min}\end{array}$} \\
\hline $4.1-6.0$ & \multicolumn{3}{|c|}{$\begin{array}{l}\text { Reduce VRIII to } 0.2-0.5 \mathrm{~mL} / \mathrm{h} \text { (stop VRIII if SC basal insulin continued) } \\
\text { Consider administration of } 10 \mathrm{~g} \text { dextrose IV to prevent CBG decreasing to }<4.0 \mathrm{mmol} / \mathrm{L} \\
\text { Repeat CBG in } 15 \mathrm{~min}\end{array}$} \\
\hline $6.1-8.0$ & 0.5 & 1 & 2 \\
\hline $8.1-12.0$ & 1 & 2 & 4 \\
\hline $12.1-16.0$ & 2 & 4 & 6 \\
\hline $16.1-20.0$ & 3 & 5 & 7 \\
\hline $20.1-24.0$ & 4 & 6 & 8 \\
\hline \multirow[t]{2}{*}{$>24.1$} & 6 & 8 & 10 \\
\hline & \multicolumn{3}{|l|}{ Seek specialist advice } \\
\hline \multicolumn{4}{|c|}{$\begin{array}{l}\text { Target CBG range } 6.0-12.0 \mathrm{mmol} / \mathrm{L} \text {. CBG up to } 12.0 \mathrm{mmol} / \mathrm{L} \text { is acceptable for a short period } \\
\text { Only increase VRIII if CBG remains high after } 3 \text { hours and is decreasing by }<3 \mathrm{mmol} / \mathrm{L} / \mathrm{h} \\
\text { There is a risk of DKA when discontinuing a VRIII, as it creates a state of acute insulin withdrawal } \\
\text { Continue SC basal insulin while using a VRIII or administer SC basal insulin } 30 \mathrm{~min} \text { before discontinuing a VRIII }\end{array}$} \\
\hline
\end{tabular}

Fig. 2. Variable rate intravenous insulin infusion regimen. ${ }^{[21,22]}(C B G=$ capillary blood glucose; $I V=$ intravenous; TDD = total daily dose; VRIII = variable rate intravenous insulin infusion; $S C=$ subcutaneous; $D K A=$ diabetic ketoacidosis.) 
Table 4. Blood glucose management according to feeding status

\begin{tabular}{|c|c|}
\hline Feeding status & Management options \\
\hline Eating normally & $\begin{array}{l}\text { Modification of usual therapy or basal-bolus SC insulin with } \\
\text { correction doses }\end{array}$ \\
\hline Fasting & VRIII, modified Alberti’s GIK, or basal insulin only* \\
\hline Tube enteral feeding & VRIII, modified Alberti's GIK, or basal insulin only* \\
\hline Total parenteral feeding & VRIII, modified Alberti's GIK, or basal insulin only* \\
\hline
\end{tabular}

Provide the diagnostic criteria and management of hypoglycaemia with every in-patient diabetes prescription

A low CBG must be interpreted in the context of the patient's feeding status and symptomatology

Decide whether the patient is at risk of hypoglycaemia unawareness. These include the frail, patients on beta-blockers, with long-standing DM, and those on medications with sedative effects. All such patients, including those under the influence of anaesthesia, should automatically be treated as symptomatic

\begin{tabular}{|c|c|c|c|c|}
\hline \multirow{2}{*}{$\begin{array}{l}\text { CBG, } \\
\mathrm{mmol} / \mathrm{L}\end{array}$} & \multicolumn{2}{|c|}{$\begin{array}{l}\text { Without symptoms and } \\
\text { signs of hypoglycaemia }\end{array}$} & \multicolumn{2}{|c|}{$\begin{array}{c}\text { With symptoms or signs of } \\
\text { hypoglycaemia }\end{array}$} \\
\hline & Normal diet & Fasting & Normal diet & Fasting \\
\hline$<4.0$ & $\begin{array}{l}\text { Provide a } \\
\text { snack and } \\
\text { repeat the } \\
\text { CBG in } 15 \text { - } \\
30 \text { min }\end{array}$ & $\begin{array}{l}\text { Give } 10 \mathrm{~g} \\
\text { dextrose IV } \\
\text { and repeat } \\
\text { the CBG in } 15 \\
-30 \mathrm{~min}\end{array}$ & $\begin{array}{l}\text { Give } 20 \mathrm{~g} \\
\text { dextrose IV } \\
\text { and repeat } \\
\text { CBG in } 15 \mathrm{~min} \\
\text { Seek urgent } \\
\text { help if no } \\
\text { response to } \\
\text { treatment }\end{array}$ & $\begin{array}{l}\text { Give } 20 \mathrm{~g} \\
\text { dextrose IV and } \\
\text { repeat CBG in } \\
15 \text { min } \\
\text { Seek urgent } \\
\text { help if no } \\
\text { response to } \\
\text { treatment }\end{array}$ \\
\hline $4.0-6.0$ & $\begin{array}{l}\text { Increase } \\
\text { monitoring } \\
\text { frequency }\end{array}$ & $\begin{array}{l}\text { Repeat CBG } \\
\text { within } 30 \mathrm{~min} \\
\text { If persistent, } \\
\text { give } 10 \mathrm{~g} \\
\text { dextrose IV } \\
\text { and increase } \\
\text { monitoring } \\
\text { frequency }\end{array}$ & $\begin{array}{l}\text { Provide a } \\
\text { snack and } \\
\text { repeat CBG in } \\
15-30 \mathrm{~min}\end{array}$ & $\begin{array}{l}\text { Give } 10 \mathrm{~g} \\
\text { dextrose IV and } \\
\text { repeat CBG in } \\
15 \text { min } \\
\text { Seek urgent } \\
\text { help if no } \\
\text { response to } \\
\text { treatment }\end{array}$ \\
\hline
\end{tabular}

Fig. 3. Management of perioperative hypoglycaemia. $(C B G=$ capillary blood glucose; $D M=$ diabetes mellitus; $I V$ = intravenous.)

that the diabetic diet provides a constant caloric intake from meal to meal and day to day. This will reduce prandial fluctuations in blood glucose and reduce the need for correction doses of insulin. The surgical team should understand the meal plan to ensure that minimal time elapses from the start of preoperative fasting until the first postoperative meal.

The local protocol should consider how care will be escalated for selected patients. Every DM patient cannot be referred to a diabetologist. Also define how feedback on perioperative DM management will be used to bring the patient back into the primary healthcare system after the perioperative period.

\section{Conclusion}

$\mathrm{DM}$ is an ever-growing public health problem affecting patient outcomes after surgery. This article addresses the SA scope of the problem and provides a structure for managing the patient with DM presenting for surgery. A local multidisciplinary team should guide practice at each facility. The recommended reading section provides essential information for individual perioperative providers and teams caring for surgical patients with DM. Where a patient scenario falls outside the scope of this discussion, the provider must consult the local multidisciplinary team or referral specialist centre for guidance.

\section{Key points}

- DM is a modifiable risk factor of adverse surgical outcomes. Undiagnosed DM or an $\mathrm{HbAlc}>8.5 \%(69 \mathrm{mmol} / \mathrm{mol})$ is an indication to postpone elective surgery.

- Monotherapy using SC short- or rapidacting insulin according to a sliding scale is not recommended.

- In all patients with DM, attempt to minimise the starvation period to only one missed meal.

- A CBG range of $6.0-10.0 \mathrm{mmol} / \mathrm{L}$ is the recommended target in the perioperative period. A CBG up to $12 \mathrm{mmol} / \mathrm{L}$ may be acceptable.

- Safe insulin prescribing practice requires prescription of hypoglycaemia treatment on every insulin prescription chart.

- In-hospital interruption of insulin therapy is a common cause of DKA in patients with type $1 \mathrm{DM}$.

- A multidisciplinary team should drive context-sensitive perioperative management of DM.

Acknowledgements. None.

Author contributions. All authors contributed to the design, research and editing of this manuscript.

Funding. None.

Conflicts of interest. None.

1. International Diabetes Federation. IDF Diabetes Atlas. 8th ed. Brussels: IDF, 2017, http://www.diabetesatlas.org (accessed 8 April 2018).

2. Shisana $O$, Labadarios D, Rehle T, et al. The South African National Health and Nutrition Examination Survey, 2012: SANHANES-1. Pretoria: Human Sciences Research Council, 2014:477-473

3. Statistics South Africa. Mortality and causes of death in South Africa, 2016: Findings from death notification. http://www. statssa.gov.za/publications/P03093/P0309320165.pdf (accessed 8 April 2018).

4. Biccard BM, Madiba TE. The South African Surgical Outcomes Study: A 7-day prospective observational cohort study. S Afr Med J 2015;105(6):465-475. https://doi.org/10.7196/SAMJ.9435

5. Davis G, Fayfman M, Reyes-Umpierrez D, et al. Stress hyperglycemia in general surgery: Why should we care? J Diabet Comp 2018;32(3):305-309. https://doi.org/10.1016/j. jdiacomp.2017.11.010

6. Duggan EW, Klopman MA, Berry AJ, Umpierrez G. The Emory University perioperative algorithm for the management of hyperglycemia and diabetes in non-cardiac surgery patients. Curr Diab Rep 2016;16(3):34. https://doi.org/10.1007/s11892 016-0720-z

7. Frisch A, Chandra P, Smiley D, et al. Prevalence and clinical outcome of hyperglycemia in the perioperative period in noncardic surgery. Diabet Care 2010:33(8):1783-1788. htps noncardiac surgery. Diabet $\mathrm{C}(\mathrm{x})$

Alycemic outcomes three years after implementation of a perioperative glycemic control algorithm in an acadric instition. Endo

Buchleitner AM, Martínez-Alonso M, Hernández M, Solà I, Mauricio D. Perioperative glycaemic control for diabetic patients undergoing surgery. Cochrane Database Syst Rev 201;(9):CD007315. https:// doi.org/10.1002/14651858.CD007315.pub2

10. Turchin A, Matheny ME, Shubina M, Scanlon JV, Greenwood B, Pendergrass ML. Hypoglycemia and clinical outcomes in patients with diabetes hospitalized in the general ward. Diabet Care 2009;32(7):1153-1157. https://doi.org/10.2337/dc08-2127

11. Barker P, Creasey PE, Dhatariya K, et al. Peri-operative management of the surgical patient with diabetes 2015: Association of Anaesthetists of Great Britain and Ireland. Anaesthesia 2015;70(12):1427-1440. https://doi.org/10.1111/ anae. 13233 
12. Dhatariya K, Levy N, Hall GM. The impact of glycaemic variability on the surgical patient. Curr Opin Anaesthesiol 2016;29(3):430-437. https://doi.org/10.1097/ACO.0000000000000326

13. The Society for Endocrinology, Metabolism and Diabetes of South Africa Type 2 Diabetes Guidelines Expert Committee. Screening and diagnosis of type 2 diabetes and intermediate hyperglycaemia. Expert Committee. Screening and diagnosis of type 2 diabetes and intermediate hyperglycaemia.
SEMDSA guideline for the management of type 2 diabetes. I Endocrinol Metab Diabet S Afr SEMDSA guideline for the
2017;22(1)(Suppl 1):S15-S19.

14. Joshi GP, Chung F, Vann MA, et al. Society for Ambulatory Anesthesia consensus statement on perioperative blood glucose management in diabetic patients undergoing ambulatory surgery. Anesth Analg 2010;111(6):1378-1387. https://doi.org/10.1213/ANE.0b013e3181f9c288

15. Levy N, Penfold NW, Dhatariya K. Perioperative management of the patient with diabetes requiring emergency surgery. BJA Educ 2016;17(4):129-136. https://doi.org/10.1093/bjaed/mkw056

16. Jaram MK. Hyperglycaemia management of type 2 diabetes mellitus inpatients in surgical wards at Livingstone Hospital. S Afr Pharmaceut J 2016;83(8):52-55.

17. Hirsch IB. Sliding scale insulin - time to stop sliding. JAMA 2009;301(2):213-214. https://doi.org/10.1001/ jama.2008.943

18. Sebranek JJ, Lugli AK, Coursin DB. Glycaemic control in the perioperative period. Br J Anaesth 2013;111(Suppl 1):i18-i34. https://doi.org/10.1093/bja/aet381

19. Hellman R. A systems approach to reducing errors in insulin therapy in the inpatient setting. Endocr Pract 2004;10(Suppl 2):100-108. https://doi.org/10.4158/EP.10.S2.100

20. National Diabetes Inpatient Audit England and Wales. 2016. http://www.digital.nhs.uk/pubs/ nadia2016 (accessed 8 April 2018).

21. Dhatariya KLN, Flanagan D, Hilton L, Kilvert A, Rayman G, Watson B. Management of adults with diabetes undergoing surgery and elective procedures: Improving standards. http://www.diabetologistsdiabetes undergoing surgery and elective procedures: Improving standards. http://WWw.
abcd.org.uk/IBDS/JBDS_IP_Surgical_Guideline_2015_Full.pdf (accessed 8 April 2018)

22. Stubbs DJ, Levy N, Dhatariya K. Diabetes medication pharmacology. BJA Educ 2017;17(6):198-207. https://doi.org/10.1093/bjaed/mkw075

23. Draznin B. Managing Diabetes and Hyperglycemia in the Hospital Setting: A Clinician's Guide. Virginia: American Diabetes Association, 2016. https://doi.org/10.2337/9781580406086

24. Partridge H, Perkins B, Mathieu S, Nicholls A, Adeniji K. Clinical recommendations in the management of the patient with type 1 diabetes on insulin pump therapy in the perioperative perio A primer for the anaesthetist. Br J Anaesth 2016;116(1):18-26. https://doi.org/10.1093/bja/aev347

25. Umpierrez GE, Smiley D, Jacobs S, et al. Randomized study of basal-bolus insulin therapy in the inpatient management of patients with type 2 diabetes undergoing general surgery (RABBIT 2 surgery). Diabet Care 2011;34(2):256-261. https://doi.org/10.2337/dc10-1407
26. The Society for Endocrinology, Metabolism and Diabetes of South Africa Type 2 Diabetes Guidelines Expert Committee. In-hospital management of hyperglycaemia. SEMDSA guideline for the Expert Committee. In-hospital management of hyperglycaemia. SEMDSA guideline for
management of type 2 diabetes. J Endocrinol Metab Diabet S Afr 2017;22(1)(Suppl 1):S68-S73.

27. Alberti K, Thomas D. The management of diabetes during surgery. Br J Anaesth 1979;51(7):693-710. https://doi.org/10.1093/bja/51.7.693

28. Polderman JA, Steen SC, Thiel B, Godfried MB. Peri-operative management of patients with type2 diabetes mellitus undergoing non-cardiac surgery using liraglutide, glucose-insulin-potassium 2 diabetes mellitus undergoing non-cardiac surgery using liraglutide, glucose-insulin-potassium
infusion or intravenous insulin bolus regimens: A randomised controlled trial. Anaesthesia 2018;73(3):332-339. https://doi.org/10.1111/anae.14180

29. Kayes MN, Prodhan NK, Malik RH. Perioperative management of diabetes: A review. Delta Med Coll J 2014;2(2):71-76. https://doi.org/10.3329/dmci.v2i2.20528

30. Khan NA, Ghali WA, Cagliero E. Perioperative management of blood glucose in adults with diabetes mellitus. UpToDate. http://www. Pertodate.com (accessed 8 April 2018).
mativative management of blood

\section{Recommended reading}

Barker P, Creasey PE, Dhatariya K. Peri-operative management of the surgical patient with diabetes. Anaesthesia 2015;70(12):1427-1440. https://doi.org/10.1111/anae.13233

Anaesthesia 2015;70(12):1427-1440. htps.//di.org/10.1111/anae.13233 jama.2008.943

Safer insulin prescribing. http://nice.org.uk/guidance/ktt20 (accessed 8 April 2018).

Safer insulin prescribing. http://nice.org.uk/guidance/ktt20 (accessed 8 April 2018).
Stubbs DJ, Levy N, Dhatariya K. Diabetes medication pharmacology. BJA Educ 2017;17(6):198-207. https:// Stubbs DJ, Levy N, Dhatariya K.
doi.org/10.1093/bjaed/mkw075

doi.org/10.1093/bjaed/mkw075
The Society for Endocrinology, Metabolism and Diabetes of South Africa Type 2 Diabetes Guidelines Expert Committee. The 2017 SEMDSA guideline for the management of type 2 diabetes. J Endocrinol Expert Committee. The 2017 SEMDSA guideline for the management of type 2 diabetes. J Endocrino Metab Diabet S Afr 2017;22(1)(Suppl 1):S1-S196.

Umpierrez GE, Smiley D, Jacobs S. Randomized study of basal-bolus insulin therapy in the inpatient management of patients with type 2 diabetes undergoing general surgery (RABBIT 2 surgery). Diabet Care 2011;34(2):256-261. https://doi.org/10.2337/dc10-1407

Accepted 3 April 2018. 